\title{
Disrupsi dan Kanonisasi Sastra ${ }^{1}$ Teguh Trianton ${ }^{2}$
}

Sekitar satu dasawarsa lalu, tepatnya pada medio tahun 2008 saya menulis sebuah esai pendek mengenai jejak sastra Banyumas. Tulisan tersebut secara ringkas medeskripsikan persoalan sulitnya mengakses informasi dan dokumen sastra karya sastrawan Banyumas Raya secara daring -melalui internet-. Bahkan situs-situs resmi milik pemerintah dearah di wilayah Banyumas Raya juga tidak menyediakan informasi yang saya maksud. Padahal, Banyumas dalam konteks geokultur memiliki khazanah sastra dan budaya yang unikum dan melimpah ${ }^{3}$.

Saat itu, saya berharap berbagai referensi terkait karya sastra, sastrawan, dan polemik kontemporer tentang kehidupan bersastra di Banyumas dapat diakses dengan gampang. Formulasi yang saya tawarkan adalah pentingnya penyusunan leksikon sastra Banyumas, beserta pernak-pernik dan polemik yang terjadi. Ini urgen, bukan hanya untuk kepentingan dokumentasi, tapi juga sebagai referensi untuk menambah khazanah kesusastraan demi kepentingan dunia pendidikan. Atau setidaknya untuk membukukan nama dan sejarah sastra Indonesia -termasuk sastra daerah atau lokal- yang berkembang di Banyumas.

Saat itu, perkembangan teknologi informasi khususnya internet dan akses data digital memang belum seriuh sekarang. Meski demikian, institusi pemerintah sudah mulai memanfaatkan internet sebagai moda berbagi informasi. Pada saat yang sama, belum banyak sastrawan yang memanfaatkan kecanggihan teknologi internet untuk mempublikasikan karya-karyanya. Mereka -sebagaian besar- masih bergantung pada media konvensional - cetak- dalam publikasi karya sastra.

$* * *$

Satu dasawarsa berselang. Hari ini kita berhadapan dengan kemudahan akses informasi. Kecanggihan teknologi digital memberikan beragam platform dan fitur yang canggih untuk saling berbagi data. Media masa dan media sosialvirtual dapat dengan gampang dipilih untuk digunakan dan ditinggalkan begitu saja. Dunia maya seolah menjelma menjadi dunia nyata. Berbagai informasi saling berseliweran, tumpang tindih, dan tanpa sensor. Setiap orang dapat menulis apa saja dan membaginya pada siapa saja dengan kecepatan tinggi atau hitungan detik. Hampir setiap kebutuhan dan hajat hidup dapat dipenuhi dengan bantuan gawai. Tidak butuh waktu lama, segalanya dapat segera tercukupi.

Era ini sering disebut era disrupsi. Suatu masa yang ditandai dengan disruption inovation pada -hampir- seluruh aspek kehidupan manusia. Inovasi teknologi yang berlangsung sangat cepat telah menggeser dan mengubah tatanan sosial dan budaya. Disrupsi telah terjadi secara masif dan meluas. Disrupsi telah

${ }^{1}$ Esai ini dipaparkan dalam forum Sarasehan Sastrawan Banyumas pada Selasa, 19 November 2019 di Aula Pendapa Wakil Bupati Banyumas. Acara ini dihelat oleh Dinas Pemuda Olahraga Kebudayaan dan Pariwisata Kabupaten Banyumas. Esai ini juga dimuat pada Rubrik Cakrawala, Tabloid Minggu Pagi, No. 38 Tahun 72, Minggu IV Desember 2019, halaman 07.

${ }^{2}$ Penyuka sastra, Peneliti Budaya, Alumnus S3 Pendidikan Bahasa Indonesia, UNS.

3 Periksa; 'Dewan Kesenian dan Jejak Sastra Banyumas', Suara Merdeka, 31 Juli 2008. 
mengubah kehidupan mulai dari sistem pemerintahan, politik, ekonomi, budaya, pendidikan, dan lain-lain.

Disrupsi secara harfiah bermakna 'hal tercerabut' atau tercerabut, yaitu sebuah kondisi tercerabutnya segala sesuatu yang telah mapan oleh kehadiran sesuatu yang baru dan tak terelakkan. Disrupsi berlangsung sangat cepat ${ }^{4}$.

Disrupsi merupakan keniscayaan yang sulit dihindari. Era ini membawa dampak ganda dan bersifat simultan; dampak positif dan negatif. Disrupsi meberikan kemudahan. Setiap orang dapat dengan cepat menjadi ahli pada suatu bidang yang tidak pernah ditekuninya. Fase ini disebut kematian pakar. Ini terjadi lantaran ilmu pengetahun berfsifat terbuka. Pada sisi lain, terbukan sistem pertukaran informasi dan pengetahuan menyebabkan hilangnya nilai dan batasbatas kebenaran. Setiap orang yang merasa menguasai informasi dapat mengklaim kebenaran menurut versinya.

$$
* * *
$$

Disrupsi dalam konteks sastra mengakibatkan perubahan yang besar, khususnya pada perkembangan produksi karya sastra, distribusi, dan munculnya sastrawan baru yang milenial. Disrupsi juga berpengaruh pada lentur dan lunturnya ukuran-ukuran estetika seni termasuk sastra. Era ini telah berhasil membaurkan antara sastra serius dan kitch, antara yang kanon dan populer.

Seseorang dengan mudah dapat menerbitkan buku sastra tanpa melalui tahap penyuntingan dan kurasi. Dengan biaya yang lebih murah; buku-buku berlabel sastra dapat diproduksi sesuai pesanan. Bahkan jamak terjadi; lantaran ingin disebut sebagai penulis untuk memenuhi kebutuhan angka kredit tertentu, seorang guru mencetak buku sastra dalam jumlah yang amat sangat terbatas. Sehingga buku yang berisi karya sastra tersebut tidak dapat ditemukan di pasaran.

Fenomena ini didukung oleh kemudahan akses penulis dengan penerbit. Jumlah penerbit buku terus bertambah. Mereka memberikan berbagai program paket penerbitan yang serba cepat dan terjangkau. Fenomena ini melahirkan sebuah kondisi 'mendadak sastra', yaitu sebuah kondisi yang menawarkan jalan pintas bagi siapa saja yang ingin disebut sebagai sastrawan dengan cara sesegera mungkin, dengan tergesa-gesa membuat karya sastra dan menerbitkannya menjadi buku.

Fenomena serupa juga jamak dilakukan menggunakan platform digital. Perekmbangan teknologi informasi memberikan kemudahan akses dan distribusi karya sastra. Siapa saja yang menguasai teknologi informasi -minimal sebagai pengguna- dapat dengan mudah memanfaatkan berbagai aplikasi pada gawai untuk membuat dan mendistribusikan karyanya ${ }^{5}$.

Kemudahan penerbitan karya sastra baik melalui paket dari penerbit mapun yang berbasis teknologi informasi digital sebenarnya merupakan peluang bagi pertumbuhan karya sastra. Para penulis sastra yang selama ini tidak punya akses atau mengalami kesulitan dalam menerbitkan sastra melalui media masa

\footnotetext{
${ }^{4}$ Rhenald Kasali mengungkapkan, setidaknya terdapat empat indikator disrupsi yaitu lebih mudah (simpler), lebih murah (cheaper), lebih terjangkau (accesible), dan lebih cepat (faster).

${ }^{5}$ Salah satu aplikasi yang memberikan kemudahan untuk mendistribusikan karya sastra adalah wattpad. Melalui aplikasi ini, siapa saja bisa menulis karya sastra dan mempublikasikan dengan segera.
} 
konvensional (cetak) dapat memilih ini sebagai siasat bersastra. Mereka yang karyanya ditolak oleh penerbit mayor dapat segera beralih ke penerbit indie dengan melakukan investasi atau membayar sesuai kemampuan dan kesepakatan.

Era disrupsi membawa udara segar bagi perkembangan sastra. Saat ini, karya sastra dengan gampang dapat diakses menggunakan gawai. Pembaca dan penikmat sastra bebas memilih karya sesuai selera. Sastra tak ubahnya seperti santapan yang siap tersaji atau terhidang. Sastra juga seolah dapat dipesan. Para penulis sastra yang jeli dengan mudah dapat meramu cerita mengikuti selera konsumen.

Pada titik ini, sastra kehilangan nilai estetiknya. Ia menjelma komoditi. Sastra ditulis bukan sebagai karya seni adi luhung, melainkan sebagai produk yang siap diperdagangkan. Menulis sastra bukan lagi sebuah kompetensi olah rasa dan pengetahuan yang harus dilakukan dengan serius. Menulis sastra berubah hanya sekedar keterampilan berbahasa. Karya sastra adalah hasil kerajinan bahasa. Sastra bukan lagi hasil karya dari budaya adi luhung, melainkan hasil produk budaya populer., sehigga disebut sebagai sastra populer. ${ }^{6}$

Sastra yang demikian tidak dapat diharapkan sebagai bagaian dari siasat kebudayaan dalam kerangka besar pembangunan karakter dan revolusi mental. Meski mudah diakses, sastra yang demikian tidak cocok digunakan sebagai bahan ajar atau bahan pengayaan pengetahuan dalam proses pendidikan di sekolah. Tidak ada yang bertanggung jawab terhadap muatan dalam karya sastra semacam itu.

Itulah sebabnya sastra kanon masih diperlukan sebagai siasat budaya dalam upaya membangun karakter anak bangsa. Sastra kanon adalah istilah untuk sastra yang dianggap abadi. Sastra yang dikekalkan secara politik sehingga langgeng sepanjang zaman. Sastra didesakkan pada pembaca melalui siasat kebudayaan di institusi pendidikan.

Kanonisasi sastra merupakan kebutuhan dalam rangka menyeleksi bahan bacaan untuk pendidikan. Kanonisasi adalah siasat atau jalan politik demi tercapainya tujuan tertentu dalam dunai pendidikan melalui sastra di era disrupsi. Prinsip dasar penciptaan sastra kanon adalah pertimbangan muatan gagasan yang mengandung nilai filosofi, nilai sejarah, mempertimbangkan aspek psikologi, dan nilai moral lainnya.

Kanonisasi bukanlah hal yang tabu. Penciptaan mahakarya atau sastra adi luhung tidak menyalahi sejarah perkembangan sastra secara umum. Lantaran sastra yang baik tidak hanya memberikan cerita melalui tokoh dalam suatu alur dan penokohan. Sastra kanon adalah sastra yang memuat berbagai gagasan atau wacana hasil pemikiran, perenungan sastrawan yang disajikan kepada pembaca secara estetik. Dengan demikian, sastra kanon tidak hanya memberikan hiburan

\footnotetext{
${ }^{6}$ istilah sastra pop atau populer diartikan sebagai sastra yang hanya terkenal (ngetop) atau eksis pada zamannya. Eksistensi sastra populer cenderung hanya belaku pada kurun waktu tertentu saja. Biasanya popularitas karya sastra ini terbatas hanya sepanjang tahun terbitnya, dan dengan segera akan lenyap tergantikan sastra pop yang baru.
} 
melalui keindahan bahasa dan cerita, tetapi mendesakan nilai-nilai yang bermanfaat bagi perkembangan jiwa pembacanya.

$$
* * *
$$

Dalam konteks Banyumas kontemporer, kita dapat menjumpai semua fenomena di atas. Perkembangan sastra di Banyumas tidak lepas dari fenomena disrupsi. Sastra di Banyumas bertumbuh dan berkembang dengan sokongan kemajuan teknologi informasi. Penulis sastra di Banyumas terlibat aktif dalam proses produksi dan ditribusi teks sastra melalui piranti lunak yang dengan mudah dapat diunduh melalui gawai.

Oleh karena itu, saya melihat pentingnya upaya kanonisasi sastra di Banyumas. Pemerintah melaui dinas dan lembaga yang kompeten, bersama para seniman, sastrawan, budayawan, dan pendidik (akademisi) duduk bersama merumuskan ukuran-ukuran sastra kanon sesuai kebutuhan dunia pendidikan di Banyumas. Sastra kanon di Banyumas adalah sastra mencerminkan realitas dan nilai budaya setempat yang selaras dengan pengetahauan dan pertumbuhan pembaca. 